\title{
Influence of Human Resource Needs on Adoption of Forest Innovations in Kenya
}

\author{
Michael O. Mukolwe1, Gilbert O. Obwoyere ${ }^{2}$, Fredrick U. Ngesa ${ }^{3}$ \\ ${ }^{1}$ Kenya Forestry Research Institute, Nairobi, Kenya \\ ${ }^{2}$ Department of Natural Resources, Egerton University, Egerton, Kenya \\ ${ }^{3}$ Department of Agricultural Education and Extension, Egerton University, Egerton, Kenya \\ Email: michaelmukolwe@yahoo.com, gobwoyere@egerton.ac.ke, ngesuf@yahoo.com
}

How to cite this paper: Mukolwe, M.O., Obwoyere, G.O. and Ngesa, F.U. (2016) Influence of Human Resource Needs on Adoption of Forest Innovations in Kenya. Open Journal of Forestry, 6, 460-475. http://dx.doi.org/10.4236/ojf.2016.65035

Received: September 14, 2016

Accepted: October 16, 2016

Published: October 19, 2016

Copyright (c) 2016 by authors and Scientific Research Publishing Inc. This work is licensed under the Creative Commons Attribution International License (CC BY 4.0).

http://creativecommons.org/licenses/by/4.0/

\section{(c) (i) Open Access}

\begin{abstract}
A combination of factors, including inadequate interactive influence of professional human resource needs, contributes to low adoption of forest innovations. This study was conducted to assess the influence of quantity of professional human resource needs on adoption of forest innovations across relevant institutions in Kenya. The study considered 51 main institutions involved in, or support conservation activities, of which 33 were public, 14 non-governmental, and 4 private. Purposive sampling was used due to the heterogeneity of the institutions involved in conservation. Primary data were collected using a structured questionnaire. A quartile graph-based quantitative model was used to establish the differences in capacity variation expressed as expected variation region or the common cause and the unexpected variation region or the special cause. The latter should be investigated and acted upon. Statistical analysis involved Levene's Test of Equality of Variances. Embracing both approaches confirmed the model as an appropriate quantitative analytical framework for assessing and articulating elements of institutional capacity, and that quantity of professional human capital $(P<0.05)$ is key to influencing adoption of forest innovations in Kenya. The study reiterates that to overcome professional capacity gaps and respond to conservation paradigm shift, quantity was relevant and was an imperative policy issue.
\end{abstract}

\section{Keywords}

Professional Human Resource, Institutional Capacity, Adoption, Forest, Innovations

\section{Introduction}

Kenya's forest resources directly and indirectly support economic growth, other productive sectors and sustainable rural development. These resources are important 
components in strategies for adapting to climate change, which is a cross-cutting issue and therefore requires special institutional arrangements (FAO, 2013; GoK, 2013a). Kenya's forest cover has been variously cited as $1.7 \%$ by UNEP, $5.6 \%$ by FAO and 6.99\% by UNFCCC (UNEP, 2001; MFWL, 2012; GoK, 2013a; KFS, 2015). However, depending on the source of statistics, the cover is still below the recommended $10 \%$ minimum international standard and Kenya's constitutional requirement (FAO, 2010; GoK, 2013a; GoK, 2014).

Forest activities contribute directly and indirectly about 3.6\% of Kenya's Gross Domestic Product (UNEP, 2012; MFWL, 2013; KFS, 2015). Kenya's estimated annual earnings from forest products and ecosystem services are in excess of Ksh. 20 billion while employing over 50,000 people directly and 300,000 indirectly (KFS, 2015). It is higher when indirect roles or social costs are quantified and contributions from the informal sector are considered (MENR, 2006; UNEP, 2012; MFWL, 2013; GoK, 2014).

The current dispersed, dismal and degraded status of Kenya's closed canopy forest cover and biodiversity in state, county and private land are a well-documented national concern (MENR, 1994; GoK, 2003; KEFRI, 2005; GoK, 2005; MENR, 2006; UNEP, 2006; GoK, 2010a; Act!, 2015). Evidently, the low forest cover has created forest resource gaps and inadequate opportunities for synergies of relevant institutions as avenues for expansion and conservation of Kenya's diverse but dismal, dispersed and degraded forest resources.

\subsection{Emerging Concern}

Most of the adoption challenges are familiar and linked to available professional human resource needs at institutional level (KARI, 2005; Kowero et al., 2006; Nair, 2006). The challenges continue to undermine initiatives to achieve sustainable management and conservation of the country's forest resources. The current paradigm shift embraces a need for pragmatic policy and participatory approach to forest conservation and management beyond the mandate, scope and capabilities of any single institution. This realisation suggests a need to: i) understand past and prevailing capacity characteristics; ii) build an objective analytical framework to assess and link capacity to pragmatic forest conservation development and adoption mechanisms across relevant institutions, and iii) identify incentives that inspire adoption of forest innovations. The purpose of this study was to assess the human resource dynamics existing within and across institutions that influence their ability to enhance adoption of forest innovations.

\subsection{Study Objectives and Hypothesis}

The broad objective of the study was to assess the influence of human resource needs on adoption of forest innovations in Kenya. It focused on assessing the quantity of professional human capital involved in influencing adoption of forest innovations, as the specific objective.

Conceptually, the institutional context was linked to the hypothesis that the quantity of human resource needs have no influence on adoption of forest innovations $\left(\mathrm{H}_{\mathrm{o}}\right)$. The 
alternative hypothesis was that the quantity of human resource needs have influence on adoption of forest innovations $\left(\mathrm{H}_{1}\right)$.

\subsection{Significance of the Study}

Adoption of forest innovations is an achievable development issue. However, understanding of what makes it happen emanates in part from adequate human resource needs and linking institutional capacity to quantity. The study informs policy on adequate quantity of human capital to influence adoption of forest innovations in Kenya.

\section{Literature Review}

\subsection{Sustainability Concept}

An important contribution of forestry to human enlightenment is the concept of sustainability (FAO, 2012). Therefore, forest resources must be actualised and sustained through emancipating institutions and stakeholders to be self-reliant, self-evaluating and proactive (Anderson \& Farrington, 1996). Nevertheless, articulating and assessing institutional human resource needs to respond to the conservation paradigm shift, still pose policy, conceptual and practical difficulties, hence infuses the debate on adoption of forest innovations and feedback challenge in Kenya's forest sector.

\subsection{Conservation Paradigm}

Tree resources are finite, hence the need for their conservation within sustainable land use management systems. Such systems must be capable of incorporating: i) biophysical, ii) prevailing socio-economic diversity in the affected areas, and iii) have capacity to capture natural succession processes, which sustain trees, forests and woodlands. Essentially, the management system should provide a higher output per unit area, with similar or less resource inputs, to be acceptable to the stakeholders. Evidently, a positive relationship between human capital and adoption of forest innovation is imperative.

\subsection{Forest Conservation Innovation Needs}

Wanjiku et al. (2013), identifies and analyses at least 46 different priority knowledge, process, and innovation or technology needs of stakeholders in different eco-regions of Kenya. The eco-regions are defined by drainage systems, land form and climate. The level of awareness and adoption of innovations varied from one eco-region to the other depending on the dissemination system used. Wanjiku et al. (2013) observed that 77\% $88 \%$ of the stakeholders in different regions were aware of the forestry and allied natural resource innovations, and that innovations should go beyond displays to influence adoption.

\subsection{Operational and Adaptive Capacities}

A conservation system that is not in touch with its clientele is considered irrelevant (Muyangu \& Jayne, 2006). Both UN Resolution 62/98 and FAO (2013) advocate for sustainable forest management as a conservation measure because it does not only 
provide the needed implementation framework, but also can be applied in all types of forest regardless of management objective(s). Institutional development has despite the many challenges aimed at creating appropriate self-supporting management structures with effective follow-up and inter-institutional linkages, particularly in forest conservation through extension.

The trigger factors include: legal and policy provisions; pressure for greater performance from fewer resources; and the need to accommodate multiple interests in forestry development as emphasised by Kenya's National Forest Programme. The capacity challenge is not only personal, professional and institutional but also interdependent (MENR, 1994; Anderson \& Farrington, 1996; Cohen \& Wheeler, 1997; GoK, 2005; World Bank, 2005; GoK 2010a).

Kenya's Constitution 2010 (GoK, 2010b), Vision 2030, Forest Policy 2014 and Forests Act No. 7 of 2005 are all committed to the changing role of forest conservation service delivery. This implies that a strengthened institutional capacity is imperative to influence adoption of forest innovations. A key pathway by which innovation is expected to have an impact is through the influence of non-technical and economic benefits.

Involving the local communities, private sector and NGOs is an important operational policy and legislative shift in forest conservation (GoK, 2005; Nair, 2006; FAO, 2009). The changes have implications on how conservation through extension is managed, contents applied, approaches and methods are articulated and linked to stakeholders, as well as on opportunities for financing conservation service in Kenya (MENR, 1994). Operational capacity challenges of conservation-related institutions, should embrace creativity to motivate conservation conditions and trends, hence the desired impact.

\subsection{Institutional Dilemma}

Institutional dilemma is imposed by legislative, policy, governance, disciplinary, fragmented information and capacity development issues, which underpin performance and adoption of forest innovations (Koech, 2006; Owino, 2007; Pannell et al., 2013; Act!, 2015). At the national level, if a solution to our environmental and natural resource management challenges is to be found in the number of institutions a country has, then Kenya need not worry. Kenya has national institutions, international agencies, NGOs, community based organisations, networks and the private sector, specifically for most known biophysical and socio-economic component of the environment.

In his foreword to the publication on Global Environment Outlook, the former UN Secretary General Dr. Kofi Annan, laments that "despite the wealth of technologies, human resources, policy options, technical and scientific information at our disposal, humankind has yet to break decisively with unsustainable and environmentally unsound policies and practices" (Annan, 2002). These sentiments are shared by other studies (Koech, 2006; Odera, 2006; Owino, 2007; MFWL, 2012).

Kowero et al. (2006) singles out capacity for forest management as probably the most limiting to effective conservation and utilisation of Africa's forest resources. Similarly, 
MENR (1994) observed that inadequate institutional capacity was a potential barrier to creating effective vertical and lateral integration of partners to enhance synergy and efficiency in adoption of forest innovations. A vital interface has yet to be created to improve performance and adoption of forest innovations in Kenya.

The values of embracing adoption include the promise of: (i) economic returns; (ii) ownership; (iii) better environmental and landscape impacts; (iv) capacity building; (v) resource endowment; and (vi) demonstrating the influence of investing in technology development. Most of these values are non-technical although Pannell et al. (2013), highlights the relative importance of economic factors as a driver of adoption.

\subsection{Capacity Assessment Initiatives}

Human capacity is important because of its relationship with performance (OECD, 2006). This implies that there is need to determine, use and appreciate the determinants of performance in relation to transforming innovations into products and services. Capacity assessment is imperative in addressing institutional gaps and operational characteristics influencing adoption of forest innovations. Assessment also leads to informed analysis of the strengths, weaknesses, opportunities and threats (SWOT) that shape forestry agenda beyond protected areas. In addition, the SWOT elements must now be meaningfully accounted for as being of a political, economic, social, technological, legislative, environmental, and governance (PESTLEG) dimension (KEFRI, 2013). The study observes that omission of component "G" to read PESTLE by choice or not, could undermine the emphasis on good governance in conservation issues.

Specific institutional capacity assessment and adoption of innovation concepts within internal and external environment have been undertaken and described by different authors (Kowero \& Spilsbury, 1997; Spilsbury et al., 1999; Thornton et al., 2000; Spilsbury et al., 2003; EuropeAid, 2005; Mulwa, 2005; Ragasa et al., 2010). Most of these studies are related to research institutions and limited assessment of conservation through extension. Despite the works, a feature of the adoption literature is its disciplinary fragmentation, which Pannell et al. (2013), attempted to harmonise.

Mulwa (2005) prescribes a rating scale approach, which is largely qualitative. They adopt a combination of the 4-point Likert scales (Likert, 1932) and the $4-7$ point scale adjectivally Semantic Differential Test (Osgood et al., 1975). The results are presented as an average score and graphically in a "radial spiderweb" design. USAID-CDIE (2011), use similar approach but without the graphical presentation and contends that where institutions meet at least $80 \%$ of their targeted improvements, it is a good measure of institutional strength and quality. Rollinson and Broadfield (2002) contend that the scaling technique is most widespread, simple and cost- effective, which could be enhanced with the availability of modern computer technology. However, its use is limited as quantification of resources, relationships and interactions between the variable is minimal. The methodology by Kowero and Spilsbury (1997), Spilsbury et al. (1999) and Spilsbury et al. (2003), is preferred as quantification of variables is at the core of 
institutional capacity assessment. The output is informed by simple, concrete and measureable data and information, hence comprehensive data underpins realisation of the model's potential, hence institutional influence adoption on forest innovations (Cheung, 2012).

\subsection{Theoretical Framework}

The processes linking human resource need characteristics to actions are critical to enhancing adoption of forest innovations. The same innovation in different circumstances can produce different effects. Within the context of adoption decision theories (Ndah et al., 2010), knowledge of the influences is central to understanding what happens, why it happens and how to make desirable events happen, when we need to (Anderson \& Farrington, 1996; Honadle, 1999).

Practical implications of the intellectual capital theory are examined as the human, social and organisational capital (Rollinson \& Broadfield, 2002; Armstrong, 2005). The infrastructural, governance and financial implications are also examined within the non-intellectual capital theory. The theories as illustrated in Figure 1, generate three

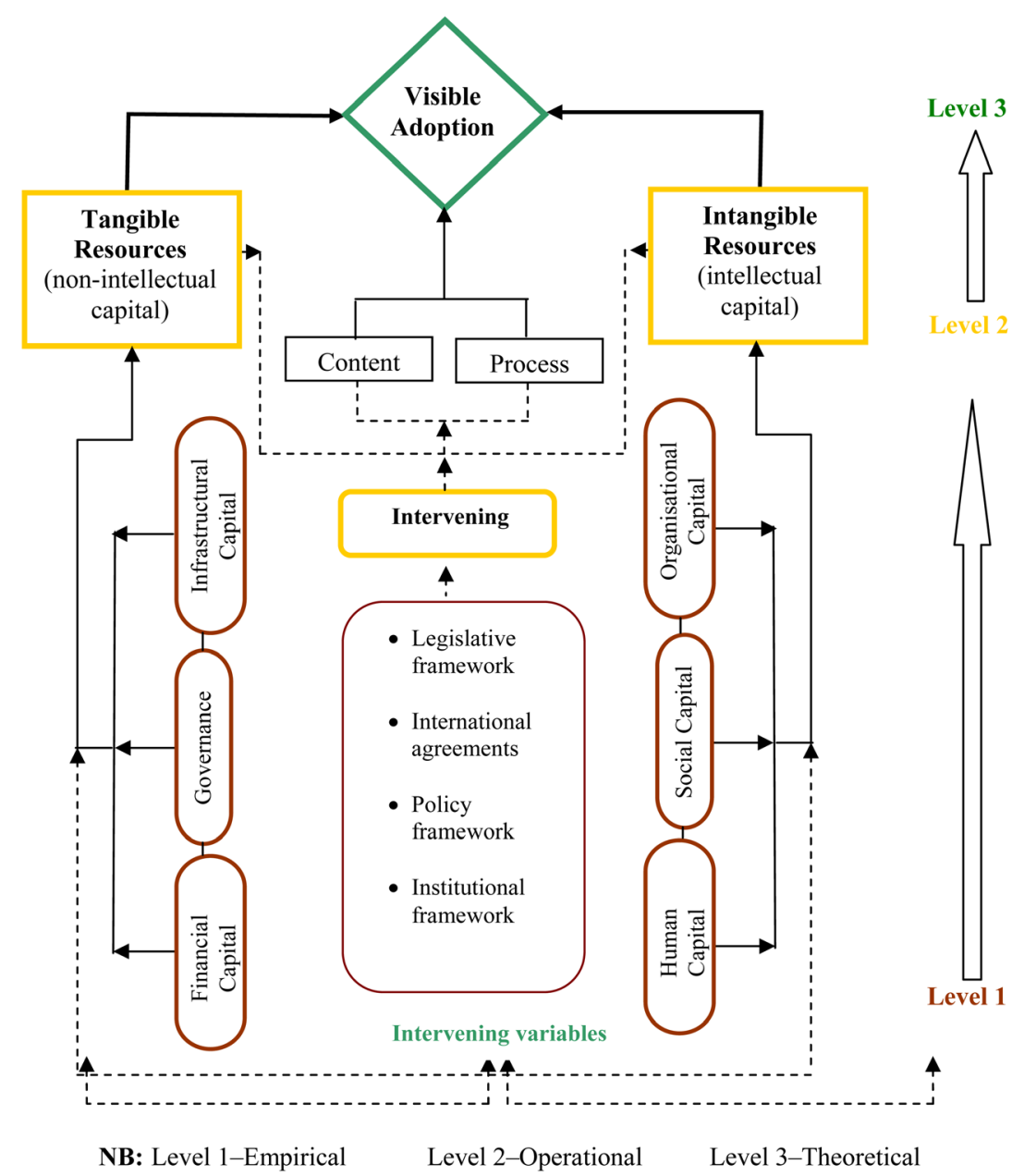

Figure 1. Theoretical framework of institutional capacity. 
practical institutional questions: What quantity has it got?, What quantity does it need now and in the future?, How is it going to attract, develop and retain these quantities to effectively influence adoption of forest innovations?

\subsection{Conceptual Framework}

The conceptual framework reiterates that impacts from adoption of forest innovations emanates from effective and efficient organisation of the institutions directly or indirectly involved in conservation and forest resource utilisation. The impact which is enriched by the interactions are therefore, visualised as aggregate of influence of adoption of forest innovations. Consequently, the conceptual framework in Figure 2, underscores the growing realisation that the many capacity elements that constitute conservation must be inclusively planned, coordinated and implemented to influence adoption of forest innovations.

The study conceptualised and envisaged the positive relationship between human capital and adoption of forest innovations as influenced by a set of variables including but not limited to legal, policy and institutional frameworks at national and county level.

\section{Research Methodology}

\subsection{Basis of Framework}

Forces driving adoption of forest innovations are complex and require an equally

Independent variables

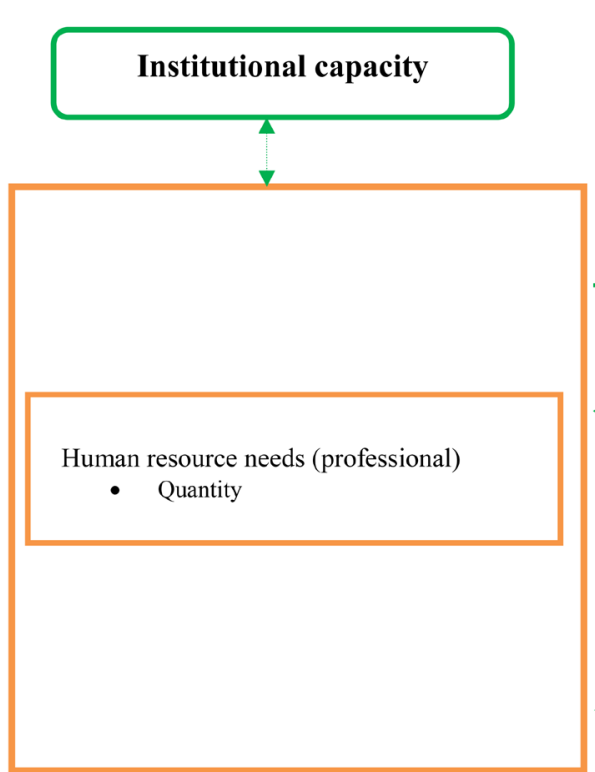

Intervening variables

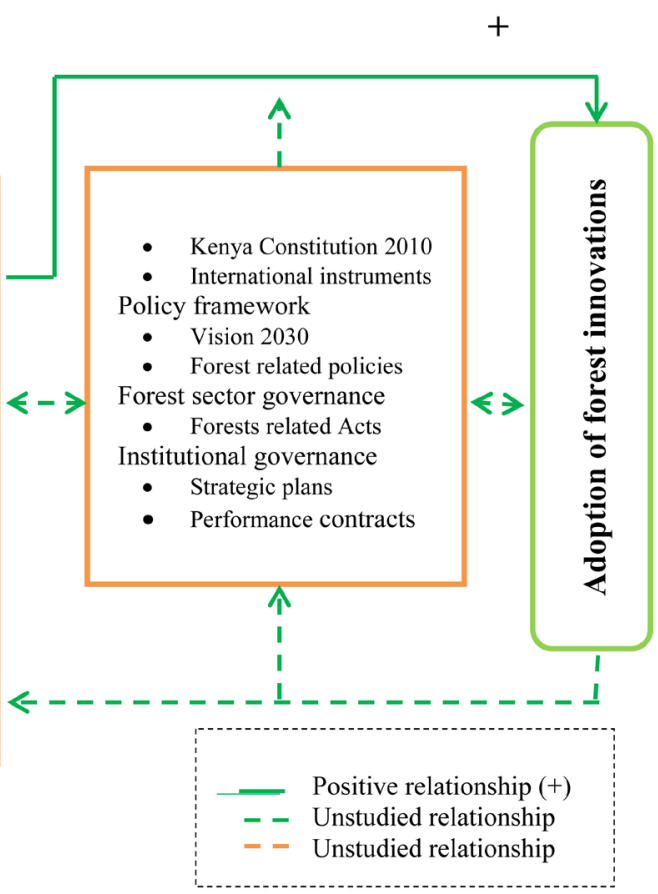

Figure 2. Conceptual framework of institutional capacity. 
complex analytical framework. Drawing from Bengston et al. (1988) and improvements by Kowero and Spilsbury (1997); Spilsbury et al. (1999); Thornton et al. (2000); Spilsbury et al. (2003); and Armstrong (2005), a similar but improved framework was used to determine the influence of human capital on adoption of forest innovations at institutional level.

\subsection{Study Area}

The study area is limited to Kenya, whose $85 \%$ of the land area is classified as arid and semi-arid (GoK, 2013b). Kenya's location, socio-economic and biophysical environment has been described by different authors (Wass, 1995; Maundu \& Tengnäs, 2005; FAO, 2010). Kenya's provisional population as at 2012 was 40.7 million people comprising about 8.8 million households (GoK, 2013b; KNBS, 2013). GoK (2013a) projects a population density of 80.3 people $\mathrm{km}^{2}$ by 2017 , which is likely to put more pressure on depletion and degradation of natural resources, hence demand on human capital to respond as appropriate.

\subsection{Research Design}

The unit of study was an institution. A cross-sectional comparative design was used to collect and analyse data from which logical conclusions were drawn (Frankfort-Nachmias \& Nachmias, 2004; KIPPRA, 2005). The study duration was in line with the Government of Kenya's financial years 2002/2003 to 2010/2011. Triangulation technique was used to indicate the contribution of each capacity indicator described by mathematical expression (1) and used in data analysis and presenting the results. Methodological flow adopted the conceptual framework shown in Figure 2.

\subsection{Population}

A population of 71 legislated or registered institutions, which are directly or indirectly involved in conservation activities, was used as a sample frame.

\subsection{Sampling Design}

According to Neuman (1997), a minimum of $10 \%$ sample size is recommended as a standard for a population of less than 100 under investigations. To minimise sampling error and achieve a higher response, the study sample size consisted of 51 respondent out of a population of the 71 legislated or registered institutions.

Purposive sampling was used due to the heterogeneity and difference in the numbers of institutions in each category. Casely and Kumar (1987) observes that above 20\% sampling ratio, the sampling error remains relatively constant. A sampling ratio of $68 \%$ was purposively used for this study. Sample sizes were stratified by category as follows: 32 public; 15 NGOs; and 4 private, all of which were surveyed. The stratification indicates that the public sector still dominates provision of conservation services in Kenya. 


\subsection{Data Collection}

Data collection involved the administration of structured questionnaire taking cognisant of validity and reliability (Neuman, 1997; Frankfort-Nachmias \& Nachmias, 2004; Phelan \& Wren, 2007). The main elements included; name of institution, vision, mission, mandate and governance, functional categories and number of professional staff involved. Prior mail contacts, visits and discussions were made with the respective heads or senior officers of relevant institutions, to obtain quantitative and qualitative information. Although attempts were made to obtain the full complement of data required, the study observed that poor record keeping, bureaucracy, and reluctance to provide particularly data on financial resources were evident.

\subsection{Data Analysis}

EXCEL was used for data entry and as a framework for the analytical quantitative model. SPSS involving Levene's Test of Equality of Variances was used for comparative data analysis to establish the quantity of professional human capital needs, show the general trends and significant associations in the variables under investigation

(http://academic.udayton.educ/gregelvers/psy216/spss.ttests.htm). The model was used to process data into values, tables and graphs to show the trends and normalised quartile values for the indicator. Each indicator value was also plotted against the sample quartile values. Quartile based-graphs were was used to establish the differences in capacity variation expressed as: i) expected variation region or the common cause, and ii) the unexpected variation region or the special cause, which should be investigated and acted on, to influence adoption of forest innovations (Bengston et al., 1988; Spilsbury et al., 2003).

Most research studies (Bengston et al., 1988; Cohen \& Wheeler, 1997; Spilsbury et al., 2003) rely on the number of staff to reflect the available capacity. In this study, human resource (HR) needs was reflected as the number of professional personnel and how it was planned to influence adoption of forest innovations. The following expression was used to quantify the influence of human capital:

$$
H R_{i}=\sum\left(G_{j}+2 q_{i}\right)+4 E
$$

where:

$i=$ conservation-related institution;

$\mathrm{G}=$ length of service of the $f^{\text {th }}$ conservation personnel: $1=$ less than four years, $2=$ four to ten years, 3 = over ten years;

$q=$ highest qualification of the $f^{\text {th }}$ conservation personnel with $0=$ Ph.D., $1=$ M.Sc., 2 = B.Sc., 3 = Diploma;

$E=$ total number of expatriate conservation personnel in the institution.

This expression reflects the relative worth of conservation personnel to a conservation-related institution. This was quantified and tabulated with respect to the qualifications (Diploma, B.Sc., M.Sc., and Ph.D.) and duration of service $(<4,4-10$ and $>10$ years) per conservation personnel within the institution. 
Quartile graphs were characterised by the following criteria: i) an indicator value at the top of the $1^{\text {st }}$ quartile reflected the maximum value or the expected highest level (absolute value $=16.0$ ) and region of excellence for that indicator in the survey sample; ii) the value on the boundary of the $2^{\text {nd }}$ and $3^{\text {rd }}$ quartile reflects the median value, which corresponds to the expected variation or common cause region, where institutions are expected to have adequate the capacities necessary for adoption of forest innovations unless a change occurs; and iii) the bottom of the $4^{\text {th }}$ quartile reflected the minimum value expressed as the unexpected variation or special cause region, whose variability should be investigated and acted upon. Thus, the model attempts to provide evidence of capacity gaps, which must be identified and addressed to allow adoption of forest innovations to thrive. However, a nil value does not necessarily imply low capacity or absence of value, but also the reluctance and uncertainty among the respondent institutions to provide data.

\section{Results and Discussion}

\subsection{Institutional Characterisation}

The study noted that the quantitative analytical model is sensitive to requirement for comprehensive data and for informed decision (Cheung, 2012). Thus, record keeping and availability of data are a critical limitation. Of the surveyed institutions, $62.7 \%$ were public, $29.4 \%$ NGOs and $7.8 \%$ private, respectively. The distribution shows that public institutions are the major players involved in, or are supporting conservation activities in Kenya. The responses represented six different institutional functional categories, namely; provision of service (PS) 33.4\%, training and research (TR) $9.8 \%$, higher and tertiary education (HT) 17.6\%, regional development (RD) 11.8\%, local authorities (LA) $17.6 \%$, and commercial (COM) at $9.8 \%$ as shown in Figure 3 . This implies that an overarching feature of the surveyed institutions was their complementary and mutually reinforcing mandates in relation to environmental conservation (Koech, 2006; UNEP, 2006).

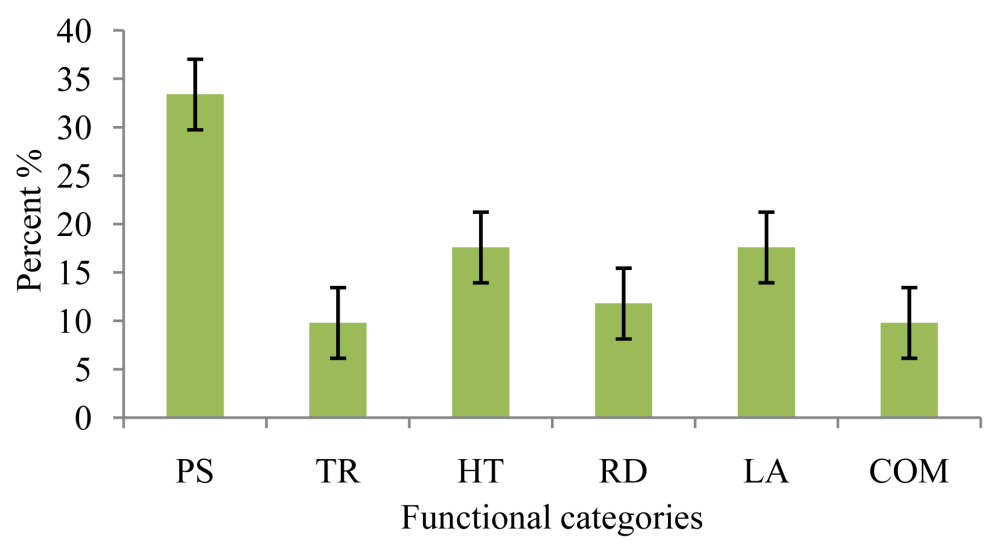

Figure 3. Distribution of quantity of professional human capital by functional categories. Provision of service (PS); Training and research (TR); Higher and tertiary education (HT) Regional development (RD); Local authorities (LA) and Commercial (COM). 
Of the 51 surveyed institutions, 45 comprising $88.2 \%$ indicated the presence of instruments of governance. This translated to majority of the sampled institutions having set down strategies that seek to define and inspire actions, and verify performance (Johnson et al., 2011).

\subsection{Distribution of Professional Human Capital among Institutions}

Table 1 shows the distribution of the professional human capital among surveyed institutions by qualification and gender. Diploma holders were relatively more than MSc, $\mathrm{BSc}$ and $\mathrm{PhD}$, respectively. The relatively higher number of MSc than BSc holders could be attributed to the suspended recruitment and opportunity for BSc holders to pursue relevant MSc in conservation programmes. Gender distribution presents a compelling need not only for the equal opportunities, but also for $70 \%$ male to $30 \%$ female as stipulated in Kenya's Vision 2030. The variance should be realised through compliance when mainstreaming gender and affirmative action as a development challenge.

\subsection{Distribution of Human Capital among Institutions}

The study established that there exist significant professional human capital gaps in the public, NGOs and private institutions warranting investigation that inform action to be taken. The human capacity (HC) grid (red line) in Figure 4 indicates a clear trend across institutions. Public institutions are best endowed in HC necessary to influence adoption of forest innovations compared to NGOs and private sector players, respectively. Similarly, NGOs are better endowed in HC compared to the private sector players.

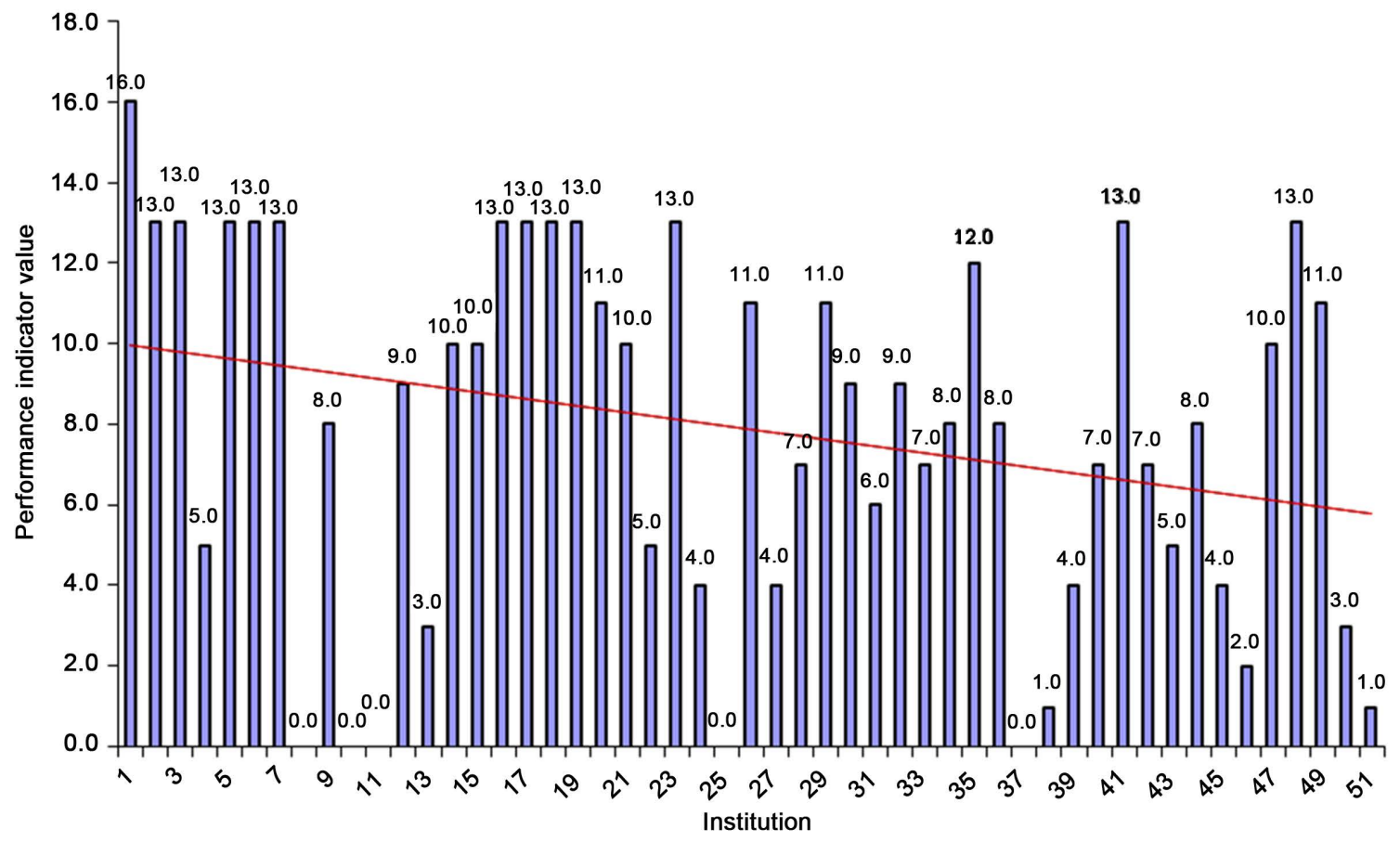

Figure 4. Distribution of human capital in institutions. 
Table 1. Distribution of professional human capital among institutions.

\begin{tabular}{cccc}
\hline Category & No. & Females & Males \\
\hline Dip & 1280 & 321 & 960 \\
BSc & 997 & 250 & 747 \\
MSc & 1178 & 295 & 883 \\
PhD & 662 & 166 & 496 \\
Total & 4117 & 1031 & 3086 \\
Percent (\%) & & 25.04 & 71.01 \\
\hline
\end{tabular}

The HC grid also indicates an upper indicator value of 10 and lower indicator value of about 6, all of which are within the quartile of "common cause" or expected variation region. Within this quartile region, institutions are expected to have all the capacities necessary for enhancing adoption of forest innovations unless, a change occurs. In this study, 6 specific institutions comprising $11.8 \%$ were observed to have underlying HC gaps or limitations, thus warranting investigation that inform actions to be taken. Of these, $66.7 \%$ were public, while private sector players and NGOs contributed about $16.3 \%$ each. The results also show that of the 51 surveyed institutions, only one had realised the highest level of performance excellence under this indicator. Therefore, adequate and effective professional personnel, is a fundamental component in enhancing adoption of forest innovations (Johnson et al., 2011).

\subsection{Comparison of Means of Quantity of Human Resources}

In testing the quantitative aspect of the hypothesis, the number of institutions with 0 30 personnel, referred to as Group 1, and those with 31 and above as Group 2 with each groups holding various qualifications, and the cumulative number of human capital in the two groups influencing adoption of forest innovation were used.

Results in Table 2 show the mean value of the quantity of professional personnel across the institutions. The standard deviations show that the dispersion of mean score is relatively high so that most institutions responded within a relatively wide range of scores. The significant difference in the means implies that the t-test does not allow the study to accept the null hypothesis $\left(\mathrm{H}_{0}\right)$. Hence, the study accepts the alternative hypothesis $\left(\mathrm{H}_{1}\right)$, thus $P<0.05$.

Since, the results are inconsistent with the null hypothesis $\left(\mathrm{H}_{0}\right)$, they confirm that across and within institutions in Kenya, the quantity of professional personnel, have influence on adoption of forest innovations.

\section{Conclusion and Recommendations}

The findings have significant policy implications for conservation initiatives through extension unlike in research. Quantity is an imperative aspect of the human capital that underpins performance and adoption of forest innovations. The fact that the human capital as described by the quantity accepts the alternative hypothesis $\left(\mathrm{H}_{1}\right)$, thus $(P<$ $0.05)$, lends credence to the prevailing capacity gap and the demand for conservation 
Table 2. Distribution of the cumulative quantity of professional personnel.

\begin{tabular}{ccccccccc}
\hline & Rank & $\mathrm{N}$ & Mean & $\mathrm{SD}$ & $\mathrm{t}$ & $\mathrm{df}$ & Sig. (2-tailed) & \multicolumn{2}{c}{ SE } \\
\hline Cumulative & 1 & 35 & 8.97 & 8.76 & -4.48 & 49 & 0.00 & 1.48 \\
& 2 & 16 & 237.69 & 305.66 & - & - & & 76.41 \\
\multirow{2}{*}{ Dip } & 1 & 35 & 4.29 & 5.23 & -2.61 & 49 & 0.01 & 0.88 \\
& 2 & 16 & 70.44 & 151.82 & & - & & 37.96 \\
BSc & 1 & 35 & 3.31 & 4.92 & -3.91 & 49 & 0.00 & 0.83 \\
& 2 & 16 & 55.00 & 78.84 & & - & & 19.71 \\
MSc & 1 & 35 & 1.03 & 1.67 & -3.69 & 49 & 0.00 & 0.28 \\
& 2 & 16 & 71.38 & 114.29 & & - & & 28.57 \\
PhD & 1 & 35 & 0.23 & 0.73 & -2.45 & 49 & 0.02 & 0.12 \\
& 2 & 16 & 40.88 & 99.25 & & - & & 24.81 \\
\hline
\end{tabular}

services. The study suggests the need to embrace pragmatic policy initiatives, public institutions to prioritise and address quantitative professional human capital needs to respond to key knowledge gaps and opportunities including professional growth. The study contributes directly to the vision, mission, and activities of forest-related institutions in Kenya as well as to the elements of Vision 2030, Forestry dialogues, National Forestry Programme and Forests Act No. 7 of 2005.

The study recommends the following added value to influence adoption of innovations:

1) Improve capacity: Public institutions should expand their portfolio of equal opportunity recruitment and continually track, identify and improve elements of human capital, as an intervention to drivers of change and ability to influence adoption of forest innovations.

2) Integrate the capacity model: Institutions should embrace the objective quantitative analytical model (Spilsbury et al., 2003; Mukolwe, 2015) to link human capital data with institutional capacity as a source of positive influence on adoption of forest innovations. Availability of comprehensive data underpins the realisation of the model's potential.

3) Inform policy on quantity of human resources needs: Inform policy at national, county level and institutional level through appropriate instruments to influence adoption of forest innovations.

\section{Declaration}

This submission has not been previously published nor before another journal for consideration.

\section{References}

Act! (2015). Environmental Footprints: Towards Sustainable Management of Natural Resources in Kenya. Nairobi: Act!. 
Anderson, J., \& Farrington, J. (1996). Forestry Extension: Facing the Challenges of Today and Tomorrow. Unasylva, 184, 3-12.

Annan, K. (2002). Foreword. In: UNEP (2002). Global Environment Outlook 3: Past, Present and Future Perspectives. xiv-xv. United Nations Environment Programme (UNEP). London: Earthscan.

Armstrong, M. (2005). A Handbook of Human Resource Management Practice (9th ed.). International Students Edition. London: Kogan Page.

Bengston, D. N., Gregersen, H. N., Lundgren, A. L., \& Hamilton, L. S. (1988). Forestry Research Capacity in the Asia-Pacific Region. Occasional Paper No. 6. Honolulu: East-West Environment and Policy Institute.

Casely, D. J., \& Kumar, K. (1987). Project Monitoring and Evaluation in Agriculture. Baltimore and London: World Bank. The John Hopkins University Press.

Cheung, P. (2012). Facing the Challenges of Measuring the Unmeasurable. DESA News, 16, No. 2. http://www.un.org/en/development/desa/newsletter/desanews/feature/2012/02/index.html

Cohen, J. M., \& Wheeler, J. R. (1997). Building Sustainable Professional Capacity in African Public Sectors: Retention Constraints in Kenya. Public Administration and Development, 17, 307324. http://dx.doi.org/10.1002/(SICI)1099-162X(199708)17:3<307::AID-PAD953>3.0.CO;2-C

EuropeAid (2005). Institutional Assessment and Capacity Development Why, What and How?: Aid Delivery Methods Concept Paper-A Contribution to Development Thinking. European Commission.

http://www.ec.europeaid/multimedia/publications/document/tools/europeaid adm concept p aper en.pdf

Food and Agriculture Organisation (2009). State of the World's Forests 2009. Rome: FAO.

Food and Agriculture Organisation (2010). Global Forest Resources Assessment 2010: Main Report. FAO Forestry Paper 163. Rome.

Food and Agriculture Organisation (2012). State of the World's Forests 2012. Rome: FAO.

Food and Agriculture Organisation (2013). Climate Change Guidelines for Forest Managers. Forestry Paper 172. Rome: FAO.

Frankfort-Nachmias, C., \& Nachmias, D. (2004). Research Methods in the Social Sciences (5th ed.). London: Arnold.

Government of Kenya (2003). Economic Recovery Strategy for Wealth and Employment Creation 2003-2007. Nairobi: Government Press.

Government of Kenya (2005). The Forests Act No. 7 of 2005. Nairobi: Government Press.

Government of Kenya (2010a). Agricultural Sector Development Strategy 2010-2020. Nairobi: Government Press.

Government of Kenya (2010b). The Constitution of Kenya 2010. Nairobi: Government Press.

Government of Kenya (2013a). Second Medium-Term Plan 2013-2017: Kenya Vision 2030Towards a Globally Competitive and Prosperous Nation. Nairobi: Ministry of Planning and Devolution.

Government of Kenya (2013b). National Climate Change Action Plan 2013-2017: Vision 2030. Nairobi: Government Press.

Government of Kenya (2014). Forest Policy, 2014. Nairobi: Ministry of Environment, Water and Natural Resources.

Honadle, G. (1999). How Context Matters: Linking Environmental Policy to People and Place. West Hartford, CT: Kumarian Press. 
Johnson, G., Scholes, K., \& Whittington, R. (2011). Exploring Strategy: Text and Case Studies (7th ed.). UK: Pearson Education Limited.

Kenya Agricultural Research Institute (2005). Strategic Plan 2005-2015. Nairobi: KARI.

Kenya Forest Service (2015). Strategic Plan 2014-2017. Nairobi: KFS.

Kenya Forestry Research Institute (2005). Strategic Plan 2005-2010. Nairobi: KEFRI.

Kenya Forestry Research Institute (2013). Strategic Plan 2013-2018. Nairobi: KEFRI.

Kenya Institute of Public Policy Research and Analysis (2005). Research Methodology and Communication. Training Manual Series, Module 3, Vol. 1: Course Book TM/01-4/2005. Nairobi: KIPPRA.

Kenya National Bureau of Statistics (2013). Kenya Facts and Figures 2013. http://www.knbs.or.ke/index.php?option=com phocadownload\&view=category\&id=20\&Itemi $\mathrm{d}=1107$

Koech, E. (2006). Forestry Extension and Education in Kenya: Historical Perspectives, Evolution, Challenges and Opportunities. In M. N. Muchiri, B. Kamondo, D. Ochieng, P. Tuwei, \& W. Wanjiku (Eds.), Proceedings of the 3rd KEFRI Scientific Conference (pp. 314-320). Nairobi: KEFRI.

Kowero, G. S., \& Spilsbury, M. J. (1997). Capacity for Forestry Research in the Southern African Development Community. Occasional Paper No. 11, Jakarta: CIFOR.

Kowero, G., Kufakwandi, F., \& Chipeta, M. (2006). Africa's Capacity to Manage Its Forests: An Overview. International Forestry Review, 8, 110-117.

Likert, R. (1932). A Technique for the Management of Attitudes. Archives of Psychology, 22, 1-55.

Maundu, P. M., \& Tengnäs, B. (Eds.) (2005). Useful Trees and Shrubs for Kenya. Technical Handbook No. 35, Nairobi: World Agroforestry Centre.

Ministry of Environment and Natural Resources (1994). Kenya Forestry Master Plan. Nairobi: Forest Department.

Ministry of Environment and Natural Resources (2006). Strategic Plan 2006-2010. Nairobi: MENR.

Ministry of Forestry and Wildlife (MFWL) (2012). Getting Kenya’s Forest Cover Right (Vol. 6, p. 2). Forestry and Wildlife News.

Ministry of Forestry and Wildlife (MFWL) (2013). Confirmed: Kenya's Forest Cover Is 7\% (Vol. 7, p. 7). Forestry and Wildlife News.

Mukolwe, M. O. (2015). Influence of Institutional Capacity on Adoption of Forest Innovation in Kenya. PhD Thesis in Natural Resources Management, Njoro: Egerton University.

Mulwa, F. W. (2005). Demystifying Participatory Development: In its Global Context Rooted in Participatory Strategic Planning. Nairobi: Zapf Chancery Research Consultants and Oliver, P.

Muyangu, M., \& Jayne, T. S. (2006). Agricultural Extension in Kenya. Draft for Review-Working Paper 2006. Tegemeo Institute of Agricultural Policy and Development, Njoro: Egerton University.

Nair, C. T. S. (2006). What Is the Future for African Forests and Forestry? International Forestry Review, 8, 4-13.

Ndah, H. T., Schuler, J., Uthes, P., \& Zander, P. (2010). Adoption Decision Theories and Conceptual Models of Innovations Systems. Leibniz-Centre for Agricultural Landscape Research (ZALLF) e.V., Session 3: Overview of Existing Modelling Approaches, Nairobi: CA2 Africa Inception Workshop.

Neuman, W. L. (1997). Social Research Methods: Qualitative and Quantitative Approaches (3rd ed.). Boston, MA: Allyn and Bacon. 
Odera, J. A. (2006). The Kenya Forestry Society: A Leading Partner in Forest Development in Kenya: Keynote Paper Presented at the Kenya Forestry Society Scientific Conference. In Proceedings of the First Kenya Forestry Society Scientific Conference (pp. 6-13). Nairobi: Kenya Forestry Society.

Organisation for Economic Cooperation and Development (2006). The Challenge of Capacity Development: Working towards Good Practice.

Osgood, C. E, May, W. H., \& Miron, M. S. (1975). Cross-Cultural Universals of Affective Meaning. Urbana, IL: University of Illinois Press.

Owino, F. (2007). Kenya "Fumble" son... Swara. East African Wildlife Society, 30, 5.

Pannell, D. J., Marshall, G. R., Barr, N., Curtis, A., Vanclay, F., \& Wilkinson, R. (2013). Understanding and Promoting Adopting of Conservation Practices by Rural Landholders. http://dpannell.fnas.uwa.edu.au/dp0502.htm

Phelan, C., \& Wren, J. (2007). Exploring Reliability in Academic Assessment. https://www.uni.edu/chfasoa/reliabilityandvalidity.htm

Ragasa, C., Babu, S., Abdullahi, A. S., \& Abubakar, B. Y. (2010). Strengthening Innovation Capacity of Nigerian Agricultural Research Organisations. IFPRI Discussion Paper 01050, International Food Policy Research Institute (IFPRI). http://www.ifpridp01050.pdf

Rollinson, D., \& Broadfield, A. (2002). Organisational Behaviour and Analysis: An Integrated Approach (2nd ed.). Gasport: Ashford Colour Press.

Spilsbury, M. J., Kowero, G. S., Mukolwe, M. O., Netzehti, A., Legesse, W. W., Nsengiyumva, O., Kiwuso, P., \& Sabas, E. (2003). Forest-Related Research Capacity in Eastern Africa. Rome: FAO.

Spilsbury, M. J., Tchala-Abina, F., \& Kowero, G. S. (1999). Capacity for Forest Research in Selected Countries of West and Central Africa. Occasional Paper No. 24, Jakarta: CIFOR.

Thornton, P. K., Randolph, T. F., Kristjanson. P. M., Omamo, W. S., Odero, A. N., \& Ryan, J. G. (2000). Assessment of Priorities to 2010 for the Poor and Environment. ILRI Impact Assessment Series No. 6, Nairobi: International Livestock Research Institute (ILRI).

United Nations Environment Programme (2001). An Assessment of the World's Remaining Closed Forests. UNEP.

United Nations Environment Programme (2006). Africa Environmental Outlook 2: Our Environment, Our Wealth. Malta: Progress Printing Press.

United Nations Environment Programme (2012). The Role and Contribution of Montane Forests and Related Ecosystem Services to the Kenyan Economy. Benefits of Forest Ecosystem_18-09-15.pdf.

United States of America Agency for International Development-Centre for Development Information and Evaluation (2011). Recent Practices in Monitoring and Evaluation: Measuring Institutional Capacity. TIPS No. 15.

Using SPSS for T-Tests: Levene's Test for Equality of Variances. http://academic.udayton.educ/gregelvers/psy216/spss.ttests.htm

Wanjiku, J., Mukolwe Mwaura, J., \& Anapapa, A. (2013). Technology Needs Assessment Survey. In J. Wanjiku, Mukolwe, J. Mwaura, \& A. Anapapa (Eds.), Proceedings of the Technology Needs Assessment Seminar. Nairobi: KEFRI Hqs.

Wass, P. (Ed.) (1995). Kenya’s Indigenous Forests: Status, Management and Conservation. Gland and Cambridge: IUCN.

World Bank (2005). Capacity Building in Africa: An OED Evaluation of World Bank Support. Washington DC: The World Bank Operations Evaluation Department. 
Submit or recommend next manuscript to SCIRP and we will provide best service for you:

Accepting pre-submission inquiries through Email, Facebook, LinkedIn, Twitter, etc. A wide selection of journals (inclusive of 9 subjects, more than 200 journals)

Providing 24-hour high-quality service

User-friendly online submission system

Fair and swift peer-review system

Efficient typesetting and proofreading procedure

Display of the result of downloads and visits, as well as the number of cited articles

Maximum dissemination of your research work

Submit your manuscript at: http://papersubmission.scirp.org/ 